\title{
Interaction between dietary content of protein and sodium chloride on milk urea concentration, urinary urea excretion, renal recycling of urea, and urea transfer to the gastrointestinal tract in dairy cows
}

\author{
J. W. Spek, ${ }^{*} \dagger^{1}$ A. Bannink, $\dagger$ G. Gort, $\ddagger$ W. H. Hendriks, ${ }^{*}$ and J. Dijkstra* \\ *Animal Nutrition Group, Wageningen University, PO Box 338, $6700 \mathrm{AH}$, Wageningen, the Netherlands \\ †Wageningen UR Livestock Research, PO Box 65, 8200 AB, Lelystad, the Netherlands \\ ¥Biometris, Wageningen University, PO Box 100, 6700 AC, Wageningen, the Netherlands
}

\begin{abstract}
Dietary protein and salt affect the concentration of milk urea nitrogen (MUN; mg of $\mathrm{N} / \mathrm{dL}$ ) and the relationship between MUN and excretion of urea nitrogen in urine (UUN; g of N/d) of dairy cattle. The aim of the present study was to examine the effects of dietary protein and sodium chloride $(\mathrm{NaCl})$ intake separately, and their interaction, on MUN and UUN, on the relationship between UUN and MUN, on renal recycling of urea, and on urea transfer to the gastrointestinal tract. Twelve second-parity cows (body weight of 645 $\pm 37 \mathrm{~kg}, 146 \pm 29 \mathrm{~d}$ in milk, and a milk production of $34.0 \pm 3.28 \mathrm{~kg} / \mathrm{d}$ ), of which 8 were previously fitted with a rumen cannula, were fitted with catheters in the urine bladder and jugular vein. The experiment had a split-plot arrangement with dietary crude protein $(\mathrm{CP})$ content as the main plot factor [116 and $154 \mathrm{~g}$ of $\mathrm{CP} / \mathrm{kg}$ of dry matter (DM)] and dietary $\mathrm{NaCl}$ content as the subplot factor (3.1 and $13.5 \mathrm{~g}$ of $\mathrm{Na} / \mathrm{kg}$ of $\mathrm{DM})$. Cows were fed at $95 \%$ of the average ad libitum feed intake of cows receiving the low protein diets. Average MUN and UUN were, respectively, $3.90 \mathrm{mg}$ of N/dL and $45 \mathrm{~g}$ of $\mathrm{N} / \mathrm{d}$ higher for the high protein diets compared with the low protein diets. Compared with the low $\mathrm{NaCl}$ diets, MUN was, on average, $1.74 \mathrm{mg}$ of $\mathrm{N} / \mathrm{dL}$ lower for the high $\mathrm{NaCl}$ diets, whereas UUN was unaffected. We found no interaction between dietary content of protein and $\mathrm{NaCl}$ on performance characteristics or on MUN, UUN, urine production, and renal clearance characteristics. The creatinine clearance rate was not affected by dietary content of protein and $\mathrm{NaCl}$. Urea transfer to the gastrointestinal tract, expressed as a fraction of plasma urea entry rate, was negatively related to dietary protein, whereas it was not affected by dietary $\mathrm{NaCl}$ content. We found no interaction between dietary protein and $\mathrm{NaCl}$ content on plasma urea entry rate and gastrointestinal urea entry rate or their
\end{abstract}

Received March 22, 2013.

Accepted June 3, 2013.

${ }^{1}$ Corresponding author: wouter.spek@wur.nl ratio. The relationship between MUN and UUN was significantly affected by the class variable dietary $\mathrm{NaCl}$ content: UUN $=-17.7 \pm 7.24+10.09 \pm 1.016 \times$ MUN $+2.26 \pm 0.729 \times \mathrm{MUN}$ (for high $\mathrm{NaCl}$ ) $; \mathrm{R}^{2}=0.85$. Removal of the MUN $\times \mathrm{NaCl}$ interaction term lowered the coefficient of determination from 0.85 to 0.77 . In conclusion, dietary protein content is positively related to MUN and UUN, whereas dietary $\mathrm{NaCl}$ content is negatively correlated to $\mathrm{MUN}$ but $\mathrm{NaCl}$ content is not related to UUN. We found no interaction between dietary protein and $\mathrm{NaCl}$ content on performance, MUN, UUN, or renal urea recycling, nor on plasma urea entry rate and urea transfer to the gastrointestinal tract. For a proper interpretation of the relationship between MUN and UUN, the effect of dietary $\mathrm{NaCl}$ should be taken into account, but we found no evidence that the effect of dietary $\mathrm{NaCl}$ on MUN is dependent on dietary protein content.

Key words: milk urea nitrogen, urinary urea nitrogen excretion, dietary $\mathrm{NaCl}$, dietary protein

\section{INTRODUCTION}

Ammonia emitted from livestock manure has negative environmental effects, including ecosystem acidification, eutrophication of surface waters, and formation of fine particulate matter formation in the atmosphere (Draaijers et al., 1989; Howarth et al., 1996). Moreover, indirect emissions of nitrous oxide $\left(\mathrm{N}_{2} \mathrm{O}\right)$, which is a major greenhouse gas, occur after atmospheric deposition of ammonia from stables and manure storage (IPCC, 2006). Livestock farming (in particular cattle operations) is considered to be a major contributor to ammonia emission (Pain et al., 1998; Hutchings et al., 2001). The primary source of ammonia emission in dairy production is excreted urinary urea N (UUN; g of $\mathrm{N} / \mathrm{d})$. Decreasing the dietary $\mathrm{CP}$ content $(\mathrm{g} / \mathrm{kg}$ of $\mathrm{DM}$ ) is one of the most effective strategies to decrease total $\mathrm{N}$ excretion and ammonia emission from animal manure (Hristov et al., 2011) and may reduce the environmental impact. 
Milk urea $\mathrm{N}(\mathrm{mg}$ of $\mathrm{N} / \mathrm{dL}$ ) is correlated with UUN, which has led to the development of several predictive models to estimate UUN from MUN (Burgos et al., 2007; Powell et al., 2011). These models assume a fixed increase of UUN per unit increase of MUN. However, several factors can affect the relationship between MUN and UUN, including BW and cow genetics, time of sampling, protein content of the diet, and the quantity of urine produced (Kauffman and St-Pierre, 2001; Aguilar et al., 2012; Spek et al., 2013). In a study by Spek et al. (2012), MUN was negatively related to $\mathrm{NaCl}$ intake, whereas UUN was not affected. From a physiological perspective, renal regulation of urea excretion can explain the effect of dietary $\mathrm{CP}$ and urine volume on the relationship between MUN and UUN. Several studies in goat, sheep, and steers show that renal processes such as the glomerular filtration rate (GFR) and recycling of urea from the glomerular filtrate are affected by CP (Thornton, 1970; Rabinowitz et al., 1973; Eriksson and Valtonen, 1982) and $\mathrm{NaCl}$ (Thornton, 1970; Godwin and Williams, 1984). Because both $\mathrm{NaCl}$ and protein intake may affect GFR and urea recycling, they might have an interactive effect on the process of renal urea excretion and MUN. The interaction between $\mathrm{NaCl}$ and protein on plasma urea nitrogen concentration $(\mathbf{P U N} ; \mathrm{mg}$ of $\mathrm{N} / \mathrm{dL}$ ) and on renal handling of urea was studied by Thornton (1970) in 2-yr-old steers. Addition of $\mathrm{NaCl}$ (200 g of $\mathrm{NaCl} / \mathrm{d}$ ) reduced PUN by $42 \%$ from 3.48 to $2.02 \mathrm{mg}$ of $\mathrm{N} / \mathrm{dL}$ at the high $\mathrm{CP}$ level $(66.9 \mathrm{~g}$ of $\mathrm{CP} / \mathrm{kg}$ of $\mathrm{DM})$, whereas it reduced PUN by only $19 \%$ from 1.15 to $0.93 \mathrm{mg}$ of $\mathrm{N} / \mathrm{dL}$ at the low $\mathrm{CP}$ level $(41.6 \mathrm{~g}$ of $\mathrm{CP} / \mathrm{kg}$ of DM). Urinary urea $\mathrm{N}$ excretion more than doubled upon $\mathrm{NaCl}$ addition at the low $\mathrm{CP}$ level, but $\mathrm{NaCl}$ addition did not affect UUN at the high CP level. Such differences suggest an interactive effect of protein and $\mathrm{NaCl}$ intake on the change in UUN per unit of change in PUN. Because MUN is a good indicator of PUN (Roseler et al., 1993), a similar interaction can be expected for MUN. It is unclear, however, whether such an interaction can be expected in lactating dairy cattle because dietary concentrations of $\mathrm{CP}$ in dairy cattle rations in practice are 3 to 4 times higher than the 40 to $70 \mathrm{~g}$ of $\mathrm{CP} / \mathrm{kg}$ of $\mathrm{DM}$ investigated by Thornton (1970). Furthermore, DMI in dairy cattle is substantially higher than that in steers in the study of Thornton (1970).

The aim of the present study was to examine the effects of protein and $\mathrm{NaCl}$ intake separately, and their interaction, on MUN, PUN, UUN, the relationship between MUN and UUN, and the GFR and reabsorption of urea from the glomerular filtrate. Another aim was to study the effect of dietary $\mathrm{CP}$ and $\mathrm{NaCl}$ on urea transfer to the gastrointestinal tract.

\section{MATERIALS AND METHODS}

\section{Cows, Housing, and Experimental Design}

The experiment was approved by the Institutional Animal Care and Use Committee of the Animal Sciences Group, Wageningen University and Research Centre (Lelystad, the Netherlands). Twelve secondparity cows, of which 8 had a rumen fistula, were selected based on milk production and presence of a rumen fistula. At the start of the experiment, the cows had BW of $645 \pm 37 \mathrm{~kg}$, milk production of $34.0 \pm$ $3.28 \mathrm{~kg} / \mathrm{d}$, and were $146 \pm 29 \mathrm{~d}$ in milk (means $\pm \mathrm{SD}$ ). Cows were housed in a tiestall to quantitatively collect urine and feces. Cows were blocked into 3 groups, according to milk production and presence of a rumen fistula. Cows within blocks were randomly assigned to 1 of 4 treatments. Treatments consisted of 2 dietary concentrations of protein (116 and $154 \mathrm{~g}$ of $\mathrm{CP} / \mathrm{kg}$ of $\mathrm{DM})$ and for each protein content 2 concentrations of $\mathrm{NaCl}$ (3.1 and $13.5 \mathrm{~g}$ of $\mathrm{Na} / \mathrm{kg}$ of $\mathrm{DM})$. The ingredients and chemical composition of the diets is presented in Table 1. The experiment had a split-plot arrangement with cow and dietary $\mathrm{CP}$ content as the main plot factors and $\mathrm{NaCl}$ content as the subplot factor. Each cow received in total 2 dietary treatments. Cows were assigned to either a low or a high protein diet, and within protein level received a low and a high dietary $\mathrm{NaCl}$ content, resulting in $\mathrm{n}=24$ observations. Because of practical limitations, measurements could be carried out on only 6 animals per day. Therefore, the 12 cows were divided into 2 groups of 6 cows each; $7 \mathrm{~d}$ after the first group of 6 cows entered the experiment, the second group of 6 cows entered the experiment. This resulted in a partial balanced design with 4 treatments and 6 cows per measurement period and a total number of 4 measurement periods. For each cow, the total length of the study was $38 \mathrm{~d}$. The first $13 \mathrm{~d}$ consisted of an adaptation period to the diet with ad libitum feed access; from d 14 until the end of the experiment, cows were fed at $95 \%$ of the average ad libitum feed intake based on the cows receiving the low protein diets, excluding $\mathrm{NaCl}$ addition. The first 2-d measurement period (collection d 24 and 25) was followed by a 10-d adaptation period to the new diet (high or low $\mathrm{NaCl}$ ) and followed by a second 2-d measurement period (collection d 37 and 38).

Cows were milked twice daily at 0500 and $1700 \mathrm{~h}$ throughout the experiment. During the noncollection days, cows were fed 2 equal meals twice daily at 0500 and $1700 \mathrm{~h}$, whereas during collection days, $67 \%$ of the daily feed allowance was provided in 8 equal meals every $2 \mathrm{~h}$, starting at $0500 \mathrm{~h}$ until $1900 \mathrm{~h}$, to minimize variation in PUN and MUN caused by variation in feed 
SPEK ET AL.

Table 1. Dietary composition (g/kg of DM unless otherwise stated) of experimental diets

\begin{tabular}{|c|c|c|c|c|}
\hline \multirow[b]{2}{*}{ Composition } & \multicolumn{2}{|c|}{ Low protein } & \multicolumn{2}{|c|}{ High protein } \\
\hline & $\begin{array}{l}\text { Low } \\
\mathrm{NaCl}\end{array}$ & $\begin{array}{l}\mathrm{High} \\
\mathrm{NaCl}\end{array}$ & $\begin{array}{l}\text { Low } \\
\mathrm{NaCl}\end{array}$ & $\begin{array}{l}\text { High } \\
\mathrm{NaCl}\end{array}$ \\
\hline \multicolumn{5}{|l|}{ Ingredient } \\
\hline Corn silage ${ }^{1}$ & 656 & 640 & 656 & 640 \\
\hline Wheat straw, chopped & 44 & 43 & 44 & 43 \\
\hline Soybean hulls & 205 & 199 & 106 & 103 \\
\hline Soybean meal protected ${ }^{2}$ & & & 131 & 127 \\
\hline Soybean meal ( $53 \%$ CP in DM) & 47 & 46 & 27 & 27 \\
\hline Limestone & 13 & 13 & 13 & 13 \\
\hline Vinasses & 5.8 & 5.7 & 5.9 & 5.7 \\
\hline Palm fatty acids & 8.3 & 8.1 & 1.3 & 1.3 \\
\hline Urea & 5.5 & 5.4 & 2.8 & 2.8 \\
\hline Feed salt ${ }^{3}$ & 5.3 & 29.9 & 5.0 & 29.6 \\
\hline Monocalcium phosphate & 5.6 & 5.5 & 2.6 & 2.6 \\
\hline Kieserite & 1.6 & 1.6 & 1.7 & 1.6 \\
\hline Magnesium oxide & 0.8 & 0.8 & 0.7 & 0.6 \\
\hline Mineral and vitamin premix ${ }^{4}$ & 2.3 & 2.2 & 2.3 & 2.3 \\
\hline \multicolumn{5}{|l|}{ Nutrient } \\
\hline $\mathrm{DM}(\mathrm{g} / \mathrm{kg}$ of feed $)$ & 473 & 481 & 473 & 473 \\
\hline $\mathrm{CP}$ & 119 & 114 & 156 & 151 \\
\hline Ash & 70.3 & 95.1 & 71.0 & 95.7 \\
\hline Crude fat & 33.5 & 34.2 & 29.8 & 31.9 \\
\hline Starch & 239 & 225 & 239 & 226 \\
\hline NDF & 383 & 412 & 362 & 372 \\
\hline $\mathrm{ADF}$ & 289 & 285 & 261 & 256 \\
\hline $\mathrm{Ca}$ & 8.5 & 8.1 & 7.6 & 7.4 \\
\hline $\mathrm{K}$ & 10.4 & 10.2 & 11.5 & 10.9 \\
\hline $\mathrm{Na}$ & 3.0 & 14.6 & 3.2 & 12.3 \\
\hline \multicolumn{5}{|l|}{ Feeding value parameter } \\
\hline $\mathrm{DVE}^{5}$ & 69 & 67 & 105 & 102 \\
\hline $\mathrm{OEB}^{6}$ & -9 & -9 & -9 & -9 \\
\hline $\mathrm{NE}_{\mathrm{L}}^{7}(\mathrm{MJ} / \mathrm{kg}$ of $\mathrm{DM})$ & 6.61 & 6.45 & 6.63 & 6.47 \\
\hline Rumen-degradable CP & 80 & 78 & 80 & 78 \\
\hline
\end{tabular}

${ }^{1}$ Corn silage (g/kg of DM unless specified otherwise): DM, $357 \mathrm{~g} / \mathrm{kg}$; CP, 73; starch, 374; NDF, 320; ADF,

180; ADL, 14; ash, 47 (determined with near-infrared spectrometry; BLGG, Wageningen, the Netherlands).

${ }^{2}$ Formaldehyde-treated soybean meal (540 g of $\mathrm{CP} / \mathrm{kg}$ of DM).

${ }^{3}$ Composition of feed salt: $\geq 99.8 \% \mathrm{NaCl}$.

${ }^{4}$ Contained per kilogram of mix: $48 \mathrm{~g}$ of $\mathrm{Ca} ; 0.8 \mathrm{~g}$ of $\mathrm{Mg} ; 6,263 \mathrm{mg}$ of $\mathrm{Cu} ; 5,010 \mathrm{mg}$ of $\mathrm{Mn} ; 10,048 \mathrm{mg}$ of $\mathrm{Zn}$; $501 \mathrm{mg}$ of I; $150 \mathrm{mg}$ of Co; $160 \mathrm{mg}$ of Se; 2.505,010 IU of vitamin A; 601,202 IU of vitamin $\mathrm{D}_{3}$; and 6,263 IU of vitamin E.

${ }^{5}$ Intestinal digestible protein (Van Duinkerken et al., 2011).

${ }^{6}$ Rumen-degraded protein balance (Van Duinkerken et al., 2011).

${ }^{7}$ Calculated with VEM (feed unit lactation) system (Van Es, 1975).

intake within a day. At $2100 \mathrm{~h}$, the remaining $33 \%$ of the total daily feed allowance was provided. Daily individual feed intake was determined by subtracting the quantity of orts from the quantity of feed supplied.

\section{Sample Collection}

The diets were prepared daily by using a paddle mixer (Holaras V.DC 1200, Hoopman Machines BV, Aalten, the Netherlands), and a representative sample ( $\sim 700 \mathrm{~g})$ of each TMR was collected daily and stored at $-20^{\circ} \mathrm{C}$. Samples of each diet for each treatment week were pooled and stored at $-20^{\circ} \mathrm{C}$ pending analyses. During sample collection days, milk yield was determined after each milking, and milk samples $(10 \mathrm{~mL})$ were obtained after each milking from the total quantity of milk. Milk samples were stored at $-20^{\circ} \mathrm{C}$ in tubes containing sodium azide pending analyses.

One day before each 2-d sample collection period, cows used for sample collection were fitted with indwelling Foley urine catheters (Ch. 26, 30-mL balloon; Bard Ltd., Crawley, UK) attached to a collection vessel. Urine catheters were removed from the cows directly after each sample collection period. The animals were also fitted with 2-way blood-sampling catheters (BD Careflow dubbel lumen, Becton Dickinson BV, Breda, the Netherlands) in the jugular vein $2 \mathrm{~d}$ before cows were used for the first time of sample collection. 
Catheters were kept open by flushing with saline solution containing $33 \mathrm{U}$ of heparin $/ \mathrm{mL}$ throughout the experiment. At each sample collection day at $0902 \mathrm{~h}$, an amount of $0.98 \pm 0.020$ and $1.92 \pm 0.016 \mathrm{~g}$ of $\left[{ }^{13} \mathrm{C}\right]$ urea $\left(99 \%{ }^{13} \mathrm{C}\right.$ enriched, Sigma-Aldrich, Zwijndrecht, the Netherlands) dissolved in $10 \mathrm{~mL}$ of saline was injected intravenously in cows on the low and high protein diets, respectively. Following infusion, the syringe was emptied and subsequently filled and emptied with blood twice to ensure that the whole $\left[{ }^{13} \mathrm{C}\right]$ urea dose entered the bloodstream. Blood samples were collected at $0900,0922,1000,1100,1200,1300,1500,1700$, and $2100 \mathrm{~h}$. These blood samples $(10 \mathrm{~mL})$ were collected in heparin tubes and centrifuged within $2 \mathrm{~h}(3,000$ $\times g$ for $15 \mathrm{~min}$ at $4^{\circ} \mathrm{C}$ ); then, the blood plasma was separated and collected before being stored at $-20^{\circ} \mathrm{C}$. Urine and feces were collected quantitatively for $24 \mathrm{~h}$ during each of the 2 consecutive collection days starting at $0500 \mathrm{~h}$. Production of urine and feces was recorded after each collection day; urine and feces were weighed, thoroughly mixed, sampled ( $\sim 250 \mathrm{~mL}$ of urine, $\sim 200 \mathrm{~g}$ of feces), and stored at $-20^{\circ} \mathrm{C}$. After the first measurement day, the urine collection vessel was replaced by a new vessel containing $364 \mathrm{~g}$ of $48 \% \mathrm{H}_{2} \mathrm{SO}_{4}$. Before a urine sample was taken, the $\mathrm{pH}$ of the collected urine was measured and additional $\mathrm{H}_{2} \mathrm{SO}_{4}$ was added if the $\mathrm{pH}$ value was above 3.0. The weight of urine recorded and urine analyses were corrected for weight and volume of sulfuric acid added. During sample collection days, at $0445 \mathrm{~h}$ and $1645 \mathrm{~h}$, rumen liquid samples (30 $\mathrm{mL}$ ) were obtained from 4 cows with a rumen fistula, put directly in ice water, and centrifuged within $30 \mathrm{~min}$ $\left(3,000 \times g\right.$ for $15 \mathrm{~min}$ at $\left.4^{\circ} \mathrm{C}\right)$; the supernatant was stored at $-20^{\circ} \mathrm{C}$.

\section{Analytical Procedures}

Dry matter content of TMR samples was determined after oven drying at $70^{\circ} \mathrm{C}$ during $24 \mathrm{~h}$ after which the dried samples were ground in a cross beater mill (Peppink, Deventer, the Netherlands) to pass a 1-mm screen. Samples were analyzed for DM (EC 152/2009; European Union, 2009), ash (EC 152/2009; European Union, 2009), N (ISO 5983; ISO,1997), crude fat (EC 152/2009; European Union, 2009), NDF (ISO 16472; ISO, 2006), ADF (ISO 13906; ISO, 2008), starch (ISO 6493; ISO, 2000a), and the minerals Ca, Na, and K (ISO 6869; ISO, 2000b) by Pre-Mervo (Utrecht, the Netherlands). Milk was analyzed for fat, protein, lactose, and SCC as described by Abrahamse et al. (2008). Milk urea content was determined using the $\mathrm{pH}$-difference technique (ISO 14637; ISO, 2004). Urea concentration in acidified urine and blood plasma samples collected at 0800,1200 , and $1700 \mathrm{~h}$ was analyzed using the urea liquicolor test (Human, Wiesbaden, Germany), which is based on measuring absorbance of light (578 nm) after a modified Berthelot reaction. Feces and acidified urine were analyzed for $\mathrm{N}$ by the Kjeldahl method with $\mathrm{CuSO}_{4}$ as the catalyst (ISO 5983; ISO, 1997). Urine was mixed and, during mixing, a sample was taken for analysis of $\mathrm{N}$ to include a proportional part of the precipitate as well. Feces were analyzed for DM (ISO 6496; ISO, 1999). Blood plasma and acidified urine samples were analyzed for creatinine by the Veterinary Diagnostic Laboratoria of Utrecht University (Utrecht, the Netherlands) by measuring absorbance of light (520 $\mathrm{nm}$ ) after a modified Jaffé reaction. Creatinine was analyzed in the individual blood plasma samples collected at 0800,1200 , and $1700 \mathrm{~h}$, to obtain an estimate of the average daily plasma creatinine concentration. Because creatinine was analyzed on a volume basis, it was necessary to estimate the volume of urine produced (as the weight and volume of added sulfuric acid is known). To this end, the specific gravity of the urine produced is required. Dividing the weight of urine by the specific gravity of urine gives the volume of urine produced. The specific gravity of urine in this study was estimated based on the relationship between specific gravity of urine and the daily urine production $(\mathrm{kg} / \mathrm{cow}$ per day) determined in a previous study of Spek et al. (2012; data on specific gravity unpublished; Figure 1). Ammonia $\left(\mathrm{NH}_{3}\right)$ in rumen liquid was determined colorimetrically using a spectrophotometer (Cary 50, Varian, Palo Alto, CA) based on the Berthelot reaction as described by Searle (1984) after deproteinizing the supernatant by addition of 10\% TCA. Enrichment of $\left[{ }^{13} \mathrm{C}\right]$ urea in blood plasma was analyzed by gas chromatography-combustion-isotope ratio mass spectrometry (GC-C-IRMS; GC type Finnigan Trace GC Ultra, Thermo Electron Corporation, Milan, Italy: IRMS type Delta V Advantage, Thermo Scientific, Bremen, Germany), using the procedure described by Dai et al. (2010).

\section{Calculations}

The creatinine (Crea) clearance rate $(\mathbf{C C R}, \mathrm{L} / \mathrm{min})$, representing the GFR or the volume of blood being filtered by the kidneys was calculated as

$\frac{\text { Total daily urinary Crea excretion }(\mathrm{mmol} / \mathrm{d})}{\text { Blood plasma Crea concentration }(\mathrm{mmol} / \mathrm{L})} / 1,440(\mathrm{~min} / \mathrm{d})$.

The urea clearance rate (UCR, L/min) was calculated as

$\frac{\text { Total daily urinary urea excretion }(\mathrm{mg} / \mathrm{d})}{\text { Blood plasma urea concentration }(\mathrm{mg} / \mathrm{L})} / 1,440(\mathrm{~min} / \mathrm{d})$. 


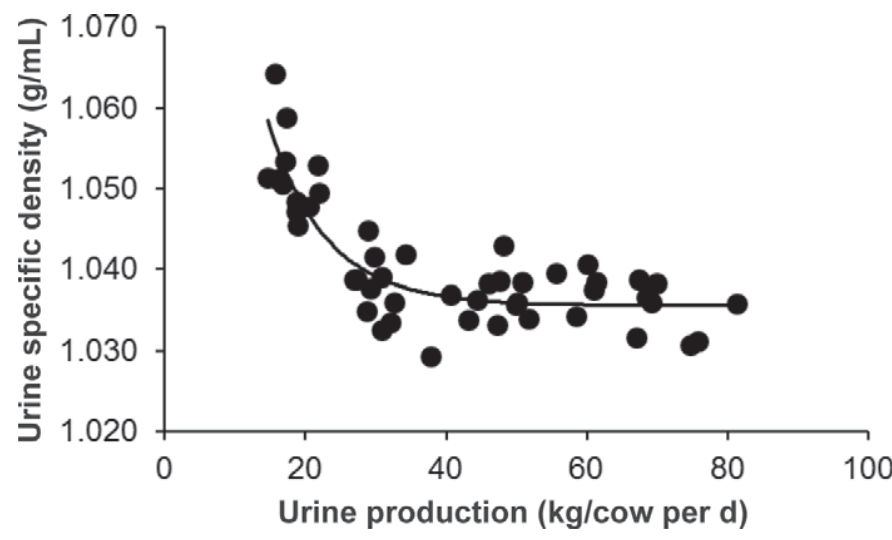

Figure 1. Relationship between urine specific density $(\mathrm{g} / \mathrm{mL})$ and urine production $(\mathrm{kg} / \mathrm{cow}$ per day, where variation in urine was caused by differences in $\mathrm{NaCl}$ intake [unpublished data of the specific gravity in urine in the study by Spek et al. (2012)]. Urine specific density (g/ $\mathrm{mL})=1.0356 \pm 0.00091+0.134 \pm 0.0590 \times \exp (-0.121 \pm 0.0267 \times$ urine production $(\mathrm{kg} /$ cow per $\mathrm{d}) ; \mathrm{R}^{2}=0.74$.

The renal urea reabsorption ratio (RRR) was calculated as: $1-(\mathrm{UCR} / \mathrm{CCR})$. The N-balance was calculated as $\mathrm{N}$-intake minus $\mathrm{N}$ excreted in milk, feces, and urine. Urea-N transfer to the gastrointestinal tract (GER) was calculated as the plasma urea- $\mathrm{N}$ entry rate (UER; $\mathrm{g}$ urea N/d) minus UUN and milk urea-N excretion rate (MUE; g of urea-N/d):

$$
\begin{aligned}
& \text { GER }(\text { g of urea-N/d) }=\text { UER }(\text { g of urea-N/d) } \\
& - \text { UUN }(\text { g of urea-N/d) - MUE }(\text { g of urea-N/d); [1] }
\end{aligned}
$$

UER was calculated by multiplying the fractional disappearance rate of plasma urea $\left(\mathbf{K}_{\text {urea }} ; / \mathrm{h}\right)$ under steadystate condition with the plasma urea pool (PUP; g of urea-N) and then multiplied by 24 :

$$
\begin{aligned}
& \text { UER }(\mathrm{g} \text { of urea-N } / \mathrm{d})=\mathrm{K}_{\text {urea }}(/ \mathrm{h}) \\
& \times \text { PUP }(\text { g of urea-N }) \times 24 .
\end{aligned}
$$

Correction of the $\left[{ }^{13} \mathrm{C}\right]$ urea atom percentage for natural enrichment (measured immediately before infusion at 09:00 h) resulted in atom percent excess (APE; \%) values for $\left[{ }^{13} \mathrm{C}\right]$ urea. The APE specifies the level of isotopic abundance above a given background level. The background level is subtracted from the experimental value to give the APE value. The $K_{\text {urea }}$ was calculated by fitting an exponential model to the APE $\left[{ }^{13} \mathrm{C}\right]$ urea enrichment data of plasma from 1000 until $2100 \mathrm{~h}$ :

$$
\text { APE }\left[{ }^{13} \mathrm{C}\right] \text { urea }(\%)=\mathrm{A} \times \exp \left(-\mathrm{K}_{\text {urea }} \times \text { time }\right),
$$

where A is the estimated APE of $\left[{ }^{13} \mathrm{C}\right]$ urea $\%$ at $0902 \mathrm{~h}$ (the time of infusion of $\left[{ }^{13} \mathrm{C}\right]$ urea).
The PUP was calculated by dividing the quantity of injected $\left[{ }^{13} \mathrm{C}\right]$ urea by the APE $\left[{ }^{13} \mathrm{C}\right]$ urea $\%$ fitted at $0902 \mathrm{~h}$ using equation [3]:

$$
\text { PUP }(\mathrm{g} \text { of urea-N })=\mathrm{g} \text { of }\left[{ }^{13} \mathrm{C}\right] \text { urea } /(\mathrm{A} / 100) \times 28 / 60 \text {. }
$$

\section{Statistical Analysis}

Observations per cow per sample collection period were averaged before statistical analysis. Effect of dietary protein and $\mathrm{NaCl}$ as class variables and the interaction between dietary protein and $\mathrm{NaCl}$ on dependent variables were evaluated as a split plot with protein content as main plot and $\mathrm{NaCl}$ content and interaction of protein with $\mathrm{NaCl}$ as subplot using the MIXED procedure in SAS (version 9.2, SAS Institute Inc., Cary, $\mathrm{NC}$ ) with dietary protein, $\mathrm{NaCl}$, and protein $\times \mathrm{NaCl}$ interaction included as fixed effects, and cow nested within protein content as random effect. The dependent variables MUN, PUN, urinary N (UN; g of $\mathrm{N} / \mathrm{d}$ ), and UUN were log-transformed before analyzing significance levels of $\mathrm{NaCl}$, protein, and the interaction between $\mathrm{NaCl}$ and protein, as the residuals of these variables tended to inflate as these values increased. Standard errors reported in the tables are the standard errors of the least squares means.

Calculation of error degrees-of-freedom was done by the DDFM = KENWARDROGER method in PROC MIXED and the covariance structure was modeled as compound symmetry. Estimation of $\mathrm{A}$ and $\mathrm{K}_{\text {urea }}$ was carried out by using the NLIN procedure of SAS. The effect of dietary $\mathrm{NaCl}$ as a class variable on the relationship between UUN and MUN (neither UUN nor MUN was log-transformed) was tested with the GLM procedure of SAS with UUN as the dependent variable and MUN and the MUN $\times$ dietary $\mathrm{NaCl}$ interaction as independent variables. Significance was declared at $P<$ 0.05 , and tendencies at $0.05 \leq P<0.10$.

\section{RESULTS}

\section{Cows, Diets, Milk Production, and MUN}

One case of mastitis and 1 case of a blocked urine catheter occurred during the measurement days, resulting in 2 missing values in the data set for $\mathrm{n}=22 \mathrm{ob}-$ servations. The average difference in Na-intake between the high and low $\mathrm{NaCl}$ diets was $199 \mathrm{~g}$ of $\mathrm{Na} / \mathrm{d}$ (Table 2 ), and the average difference in $\mathrm{N}$-intake between the high and low protein diets was $130 \mathrm{~g}$ of $\mathrm{N} / \mathrm{d}$ (Table $3)$. The DMI tended to be higher $(P=0.065)$ for the cows receiving the high protein diets compared with cows receiving the low protein diets (Table 2). Com- 
Table 2. Effect of dietary protein and $\mathrm{NaCl}$ content on intake of $\mathrm{Na}$ and $\mathrm{N}$, DMI, milk production, milk composition, rumen ammonia concentration, and apparent digestibility of feed DM in lactating dairy cows ${ }^{1}$

\begin{tabular}{|c|c|c|c|c|c|c|c|c|}
\hline \multirow[b]{2}{*}{ Parameter } & \multicolumn{2}{|c|}{ Low protein } & \multicolumn{2}{|c|}{ High protein } & \multirow[b]{2}{*}{ SE } & \multicolumn{3}{|c|}{$P$-value } \\
\hline & $\begin{array}{l}\text { Low } \\
\mathrm{NaCl}\end{array}$ & $\begin{array}{l}\text { High } \\
\mathrm{NaCl}\end{array}$ & $\begin{array}{l}\text { Low } \\
\mathrm{NaCl}\end{array}$ & $\begin{array}{l}\text { High } \\
\mathrm{NaCl}\end{array}$ & & Protein & $\mathrm{NaCl}$ & $\begin{array}{l}\text { Protein } \\
\times \mathrm{NaCl}\end{array}$ \\
\hline Na-intake $(\mathrm{g} / \mathrm{d})$ & 58 & 273 & 62 & 244 & 10.2 & 0.263 & $<0.001$ & 0.110 \\
\hline DMI $(\mathrm{kg} / \mathrm{d})$ & 19.2 & 19.3 & 19.6 & 20.0 & 0.28 & 0.068 & 0.383 & 0.507 \\
\hline Milk yield $(\mathrm{kg} / \mathrm{d})$ & 22.4 & 22.0 & 24.7 & 26.5 & 1.03 & 0.028 & 0.285 & 0.126 \\
\hline $\operatorname{FPCM}^{2}(\mathrm{~kg} / \mathrm{d})$ & 23.3 & 23.7 & 25.0 & 26.1 & 1.18 & 0.228 & 0.115 & 0.517 \\
\hline Protein $(\%)$ & 3.34 & 3.45 & 3.48 & 3.29 & 0.142 & 0.961 & 0.691 & 0.162 \\
\hline Lactose (\%) & 4.48 & 4.54 & 4.59 & 4.54 & 0.099 & 0.651 & 0.907 & 0.379 \\
\hline $\mathrm{SCC}(\times 1,000$ cells $/ \mathrm{mL})$ & 144 & 185 & 90 & 100 & 33.3 & 0.123 & 0.279 & 0.500 \\
\hline Rumen $\mathrm{NH}_{3}(\mathrm{mg}$ of $\mathrm{N} / \mathrm{L})$ & 32.9 & 36.7 & 45.4 & 36.2 & 4.25 & 0.257 & 0.554 & 0.182 \\
\hline $\operatorname{ATTD}^{3}(\%)$ & 65.4 & 67.2 & 70.2 & 70.4 & 0.92 & 0.002 & 0.265 & 0.390 \\
\hline
\end{tabular}

${ }^{1}$ Values are least squares means.

${ }^{2}$ Fat- and protein-corrected milk: $(0.337+0.116 \times$ fat $\%+0.06 \times$ protein $\%) \times$ milk yield $(\mathrm{kg} / \mathrm{d})$.

${ }^{3}$ Apparent total-tract digestibility of DM.

pared with that in the low protein treatments, milk production in the high protein treatments was $3.4 \mathrm{~kg} / \mathrm{d}$ higher $(P=0.028$; Table 2$)$. However, milk production corrected for fat and protein content (FPCM) did not differ significantly between low and high protein treatments. Milk concentrations of fat, protein, lactose, and SCC were not related to dietary content of protein and $\mathrm{NaCl}$. Milk urea nitrogen concentration was positively affected by protein intake $(P<0.001)$ and negatively by $\mathrm{NaCl}$ intake $(P=0.002)$. Compared with that of the low protein treatments, MUN was $3.90 \mathrm{mg}$ of N/dL higher for the high protein treatment. Compared with that of the low $\mathrm{NaCl}$ treatments, MUN was $1.74 \mathrm{mg}$ of $\mathrm{N} / \mathrm{dL}$ lower for the high $\mathrm{NaCl}$ treatments. We observed no interaction effect between dietary content of protein and $\mathrm{NaCl}$ on $\mathrm{MUN}(P=0.314)$ or on milk production and milk composition (Table 2).

\section{UUN-MUN Relationship}

We found a significant interaction effect $(P=0.006)$ of dietary $\mathrm{NaCl}$ (class variable) on the relationship between UUN and MUN: UUN ( $\mathrm{g}$ of $\mathrm{N} / \mathrm{d})=-17.7 \pm$ $7.24+10.09 \pm 1.016 \times$ MUN $(\mathrm{mg}$ of $\mathrm{N} / \mathrm{dL})+2.26 \pm$ $0.729 \times$ MUN $(\mathrm{mg}$ of $\mathrm{N} / \mathrm{dL}) \times \mathrm{NaCl}($ for high $\mathrm{NaCl})$, $\mathrm{R}^{2}=0.85$ (Figure 2). Removal of the MUN $\times \mathrm{NaCl}$ interaction term lowered the coefficient of determination from 0.85 to 0.77 .

\section{Nitrogen Flows}

Milk-N, fecal-N, and UN were all affected by protein content but not by $\mathrm{NaCl}$ content (Table 3). Compared with the low protein diets, high protein diets increased excretion of milk-N (19 g of N/d), fecal-N (16 g of

Table 3. Effect of dietary protein and $\mathrm{NaCl}$ content on excretion of $\mathrm{N}$ in milk, urine, and feces, and on urea and non-urea $\mathrm{N}$ excretion in lactating dairy cows ${ }^{1}$

\begin{tabular}{|c|c|c|c|c|c|c|c|c|}
\hline Parameter $(\mathrm{g}$ of $\mathrm{N} / \mathrm{d})$ & \multicolumn{2}{|c|}{ Low protein } & \multicolumn{2}{|c|}{ High protein } & $\mathrm{SE}$ & \multicolumn{3}{|c|}{$P$-value } \\
\hline N-milk & 120 & 122 & 138 & 141 & 5.0 & 0.021 & 0.371 & 0.912 \\
\hline $\mathrm{N}$-feces & 137 & 128 & 149 & 148 & 4.4 & 0.008 & 0.228 & 0.369 \\
\hline N-urine & 77 & 69 & 128 & 130 & 7.2 & $<0.001$ & 0.495 & 0.373 \\
\hline NUUN $^{4}$ & 43 & 41 & 51 & 55 & 3.9 & 0.013 & 0.725 & 0.436 \\
\hline
\end{tabular}

\footnotetext{
${ }^{1}$ Values are least squares means.

${ }^{2}$ Calculated as $\mathrm{N}$-intake minus excretion of $\mathrm{N}$ in milk, feces, and urine.

${ }^{3}$ Urinary urea-N excretion.

${ }^{4}$ Urinary non-urea-N excretion.
} 


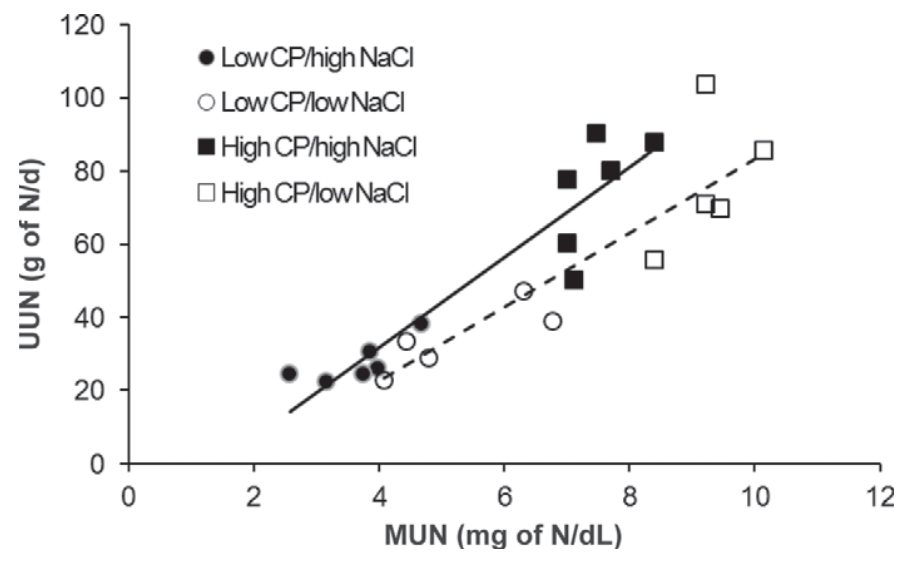

Figure 2. Relationship between MUN concentration (mg of N/dL) and urinary urea nitrogen excretion (UUN; $g$ of $\mathrm{N} / \mathrm{d}$ ) for low $\mathrm{NaCl}$ (3.1 $\mathrm{g}$ of $\mathrm{Na} / \mathrm{kg}$ of DM; dashed regression line) and high $\mathrm{NaCl}(12.9$ $\mathrm{g}$ of $\mathrm{Na} / \mathrm{kg}$ of $\mathrm{DM}$; solid regression line) diets. UUN $=-17.7 \pm 7.24$ $+10.09 \pm 1.016 \times \mathrm{MUN}+2.26 \pm 0.729 \times \mathrm{MUN}$ (for high $\mathrm{NaCl}$ ); $\mathrm{R}^{2}$ $=0.85$.

$\mathrm{N} / \mathrm{d}$ ), UN (56 g of $\mathrm{N} / \mathrm{d}$ ), UUN (46 $\mathrm{g}$ of $\mathrm{N} / \mathrm{d}$ ), and non-urinary-urea-N (11 g of $\mathrm{N} / \mathrm{d})$. Also, the average $\mathrm{N}$-balance was $38 \mathrm{~g}$ of $\mathrm{N} / \mathrm{d}$ higher for the high protein diets. No interaction between dietary content of protein and $\mathrm{NaCl}$ on $\mathrm{N}$-flows was present (Table 3 ).

\section{Renal Functioning}

Compared with the low $\mathrm{NaCl}$ diets, the high $\mathrm{NaCl}$ diets had, on average, a $116 \%$ higher urine production $(32.3$ vs. $15.0 \mathrm{~kg} / \mathrm{d})$, a tendency $(P=0.080)$ toward a lower plasma creatinine concentration (63.7 vs. 66.4 $\mu \mathrm{mol} / \mathrm{L})$, a $16 \%$ lower PUN (9.10 vs. $10.86 \mathrm{mg}$ of $\mathrm{N} /$ $\mathrm{dL}$ ), and a $20 \%$ higher UUN:MUN ratio (8.91 vs. 7.40 ) (Table 4). Compared with the low protein diets, the high protein diets had a $68 \%$ higher PUN (12.51 vs. $7.45 \mathrm{mg}$ of $\mathrm{N} / \mathrm{dL}$ ), a $29 \%$ higher UUN:MUN ratio (9.17 vs. 7.13), and a $45 \%$ increase in renal $\mathrm{UCR}(\mathrm{L} / \mathrm{min}$; 0.421 vs. $0.290 \mathrm{~L} / \mathrm{min})$. We observed no interaction between dietary content of $\mathrm{NaCl}$ and protein on any parameter tested (Table 4).

\section{Rumen Ammonia and Feed Digestibility}

Apparent total-tract digestibility of feed dry matter (ATTD; \%) was positively related to dietary protein content but not to dietary $\mathrm{NaCl}$ content (Table 2). The concentration of rumen $\mathrm{NH}_{3}$ was not related to dietary protein (Table 2).

\section{Urea Transfer to the Gastrointestinal Tract}

The $\left[{ }^{13} \mathrm{C}\right]$ urea observations at $0922 \mathrm{~h}$ were not included in the analysis as these observations were too high, highly variable, and not in line with the decline in $\left.{ }^{13} \mathrm{C}\right]$ urea observed for the other sampling time points (Figure 3), resulting in a substantially reduced model fit. Presumably, the injected $\left[{ }^{13} \mathrm{C}\right]$ urea bolus did not completely disperse over the entire urea distribution volume within the first $20 \mathrm{~min}$ after infusion. The fractional disappearance rate of plasma urea was negatively related to dietary protein content, whereas PUP, UER, and GER were positively related (Table 5). As a fraction of dietary N-intake, UER and GER were not significantly affected by dietary protein level or by dietary $\mathrm{NaCl}$ level. However, the GER:UER ratio, or the fraction of UER that is returned to the gastrointestinal tract, was negatively related to dietary protein level (Table 5). The UER was negatively related to dietary $\mathrm{NaCl}$ level, whereas $\mathrm{K}_{\text {urea, }}$ PUP, the GER:N-intake ratio, and the GER:UER ratio were not related to dietary $\mathrm{NaCl}$ level. The GER $(P=0.076)$ and the UER:Nintake ratio $(P=0.076)$ tended to be negatively related to dietary $\mathrm{NaCl}$.

Table 4. Effect of protein and $\mathrm{NaCl}$ content on urine volume, urinary creatinine excretion (CREA), plasma creatinine concentration (PCC), plasma urea nitrogen concentration (PUN), ratio between urinary urea nitrogen excreted (UUN; g of N/d) and the concentration of MUN (mg of $\mathrm{N} / \mathrm{dL}$ ), urea clearance rate (UCR), creatinine clearance rate $(\mathrm{CCR})$, and renal recycling ratio of urea (RRR) in lactating dairy cows ${ }^{1}$

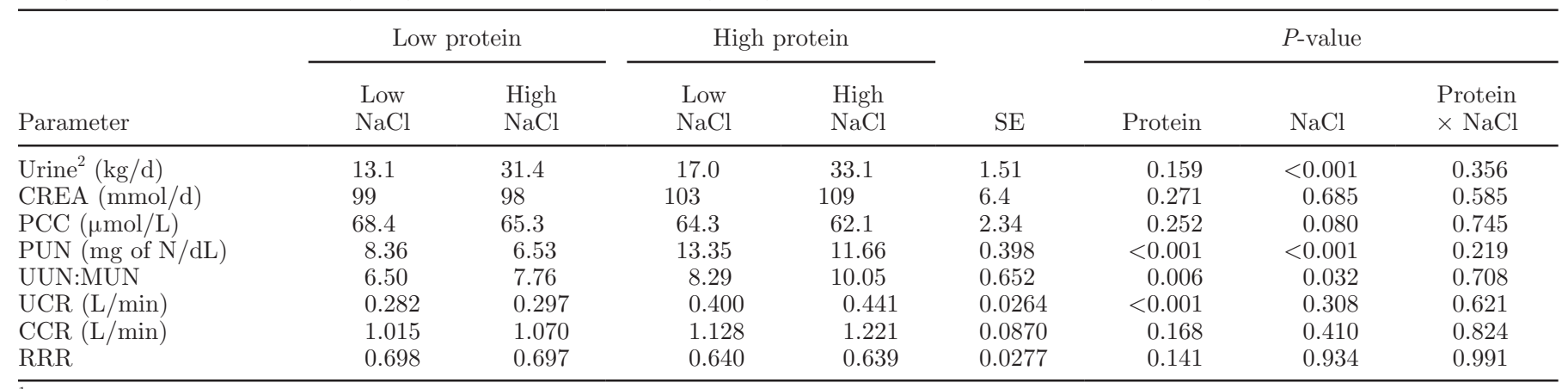

${ }^{1}$ Values are least squares means.

${ }^{2}$ Excluding sulfuric acid added to the urine collection vessels. 
Table 5. Effect of dietary protein and $\mathrm{NaCl}$ on plasma urea pool size and urea transfer characteristics in lactating dairy cows ${ }^{1}$

\begin{tabular}{|c|c|c|c|c|c|c|c|c|}
\hline Parameter & \multicolumn{2}{|c|}{ Low protein } & \multicolumn{2}{|c|}{ High protein } & SE & \multicolumn{3}{|c|}{$P$-value } \\
\hline $\mathrm{PUP}^{3}(\mathrm{~g}$ of urea-N) & 30.6 & 25.5 & 48.9 & 45.6 & 2.48 & $<0.001$ & 0.108 & 0.726 \\
\hline $\mathrm{UER}^{4}$ (g of urea-N/d) & 226 & 199 & 315 & 292 & 11.8 & $<0.001$ & 0.020 & 0.825 \\
\hline $\mathrm{GER}^{5}(\mathrm{~g}$ of urea-N/d) & 189 & 170 & 234 & 215 & 12.4 & 0.012 & 0.076 & 0.960 \\
\hline GER:UER & 0.842 & 0.853 & 0.744 & 0.737 & 0.0211 & $<0.001$ & 0.904 & 0.678 \\
\hline
\end{tabular}

${ }^{1}$ Values are least squares means.

${ }^{2}$ Fractional disappearance rate of plasma urea-N.

${ }^{3}$ Plasma urea pool.

${ }^{4}$ Plasma urea entry rate.

${ }^{5}$ Gastrointestinal urea entry rate.

\section{DISCUSSION}

\section{Cows, Diets, Milk Production, and MUN}

Although this study aimed to minimize differences in DMI between treatments by feeding cows at $95 \%$ of the average ad libitum feed intake for the low protein diets during the adaptation period, DMI for the high protein treatments tended $(P=0.068)$ to be higher by $0.6 \mathrm{~kg} / \mathrm{d}$. A $6 \%$ higher ATTD was observed for the high protein diets. This finding indicates reduced fermentation of feed in the gastrointestinal tract at the low protein level, which may have caused an increased rumen fill and reduced feed intake. A suboptimal rumen $\mathrm{NH}_{3}$ concentration would be a logical explanation for the reduced ATTD at the low protein diets. However, level of rumen $\mathrm{NH}_{3}$ was not significantly affected by dietary

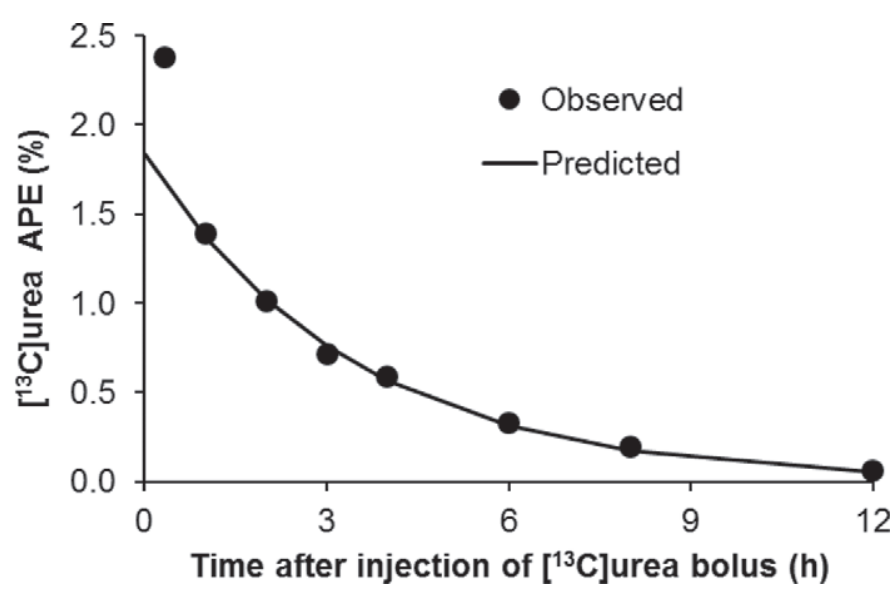

Figure 3. Example of an average result of a regression (excluding the data point at 20 min after injection of a $\left[{ }^{13} \mathrm{C}\right]$ urea bolus; see Materials and Methods for further explanation) of dilution of $\left[{ }^{13} \mathrm{C}\right]$ urea in plasma after injection of a $\left[{ }^{13} \mathrm{C}\right]$ urea bolus. $\mathrm{APE}=$ atom percent excess. protein content (Table 2), and low and high protein diets were formulated in such a way to have similar quantities of RDP and a similar RDP balance (Table 1). The slightly negative dietary RDP balance resulted in $\mathrm{NH}_{3}$ levels $(32.9-45.4 \mathrm{mg}$ of $\mathrm{N} / \mathrm{L})$ that were below the levels of $\mathrm{NH}_{3}$ considered sufficient for optimal microbial protein synthesis (Satter and Slyter, 1974). Milk production was higher for the high protein diets $(25.6 \mathrm{~kg}$ of milk/d) compared with the low protein diets $(22.2 \mathrm{~kg}$ of milk/d). This difference of $3.4 \mathrm{~kg}$ of milk/d is slightly lower than the milk yield response to changes in dietary CP content predicted according to NRC (2001; namely, $4.1 \mathrm{~kg} / \mathrm{d}$ ). However, differences in FPCM were much smaller and not significantly different. Compared with the low protein diets, the $15 \%$ higher, on average, $\mathrm{N}$ excretion in milk for the high protein diets suggests that the low protein diet limited milk production. Several factors might explain this lower milk production for the low protein diets in the present study. First, the ATTD of feed was reduced for the low protein diets, resulting in less energy available for milk protein production and possibly less efficient utilization of absorbed protein for milk protein synthesis. Second, the feed intake for the low protein diets was some $0.6 \mathrm{~kg}$ of $\mathrm{DM} / \mathrm{d}$ lower, resulting in less energy and protein available for milk protein production. Third, the ratio of urea- $\mathrm{N}$ to total dietary $\mathrm{N}$ in the low protein diets (0.136) was higher than that in the high protein diets $(0.053)$ in the present study. Several studies have shown that the ratio of true protein to dietary $\mathrm{CP}$ is positively related to milk production (Polan et al., 1976; Brito and Broderick, 2007; Broderick and Reynal, 2009). The effect of dietary protein concentration on MUN in this study is in line with results from other studies with similar ranges in dietary CP content (Korhonen et al., 2002; Colmenero and Broderick, 2006). The average decrease in MUN of $0.88 \mathrm{mg}$ of N/dL per $100 \mathrm{~g} / \mathrm{d}$ of $\mathrm{Na}$ intake 
is similar to the decrease in observed PUN in the study of Weeth and Haverland (1961) of $0.85 \mathrm{mg}$ of N/dL per $100 \mathrm{~g} / \mathrm{d}$ of $\mathrm{Na}$ intake, but larger than the decrease in MUN of $0.68 \mathrm{mg}$ of $\mathrm{N} / \mathrm{dL}$ observed in another recent trial by Spek et al. (2012). No interaction between dietary $\mathrm{NaCl}$ and protein content on MUN was found. An interaction effect was anticipated based on the 42 and $19 \%$ decreases of PUN upon supply of $200 \mathrm{~g}$ of $\mathrm{Na} / \mathrm{d}$ observed with high and low protein diets, respectively, in steers by Thornton (1970). Dietary concentrations of protein in the study of Thornton (1970) of 67 and 42 $\mathrm{g}$ of $\mathrm{CP} / \mathrm{kg}$ of $\mathrm{DM}$ for the high and low protein diets, respectively, were substantially lower than the 154 and $116 \mathrm{~g}$ of $\mathrm{CP} / \mathrm{kg}$ of DM in the present study. Perhaps an interactive effect of dietary $\mathrm{NaCl}$ and protein on MUN or PUN is only present at extremely low dietary protein contents.

\section{UUN-MUN Relationship}

Compared with the low salt diets, the higher $(P=$ $0.006)$ excretion of $2.26 \pm 0.729 \mathrm{~g}$ of urinary urea-N per unit increase in MUN for the high salt diets was in line with results from Spek et al. (2012), where dietary $\mathrm{NaCl}$ was negatively related to MUN but not to UUN. The amount of explained variation in UUN increased from 77 to $85 \%$ when $\mathrm{NaCl}$ level was included in the model. The variation in dietary urine levels of 13.1 to $33.1 \mathrm{~kg} / \mathrm{d}$ in the present study, caused by variation in $\mathrm{NaCl}$ intake, is observed in practice and comparable to urine production levels observed by De Campeneere et al. (2006) for diets based on maize silage $(14.4 \mathrm{~L} / \mathrm{d})$ and grass silage $(35.0 \mathrm{~L} / \mathrm{d})$. This improved explanation of UUN by taking $\mathrm{NaCl}$ level, as well as MUN, into account is relevant for the dairy industry because MUN is often used as an indicator for protein nutrition and UUN.

\section{Nitrogen Flows}

The positive effect of dietary CP content on N-excretion in milk is consistent with other studies that varied concentrations of CP (Gonda et al., 1995; Korhonen et al., 2002; Colmenero and Broderick, 2006). Colmenero and Broderick (2006) observed a reduction in absolute fecal N-excretion upon an increase in dietary CP from 13.5 to $15.0 \%$ in DM, and Ruiz et al. (2002) observed no absolute increase in fecal $\mathrm{N}$ excretion upon an increase in CP from 11.1 to $14.1 \%$ in DM. Both studies show that excretion of fecal $\mathrm{N}$ did not increase as levels of dietary CP increased. This was, however, not the case in the present study, probably as the result of (1) the high content of formaldehyde-treated soybean meal in the high protein diets that was less digestible than the high content of urea and untreated soybean meal provided in the low protein diet, and (2) the average 0.6-kg-higher DMI for the high protein diets as DMI is positively related to fecal $\mathrm{N}$ excretion (Huhtanen et al., 2008). Also, the quantity of non-urea-urinary-N (NUUN; g N/d) was larger for the high protein diets. This result might be attributed to a higher excretion of purine derivatives in the urine originating from rumensynthesized microbial protein. More microbial protein may have been synthesized with the high protein diets because of the higher efficiency of microbial protein synthesis on true protein compared with ammonia as the N source in RDP (Argyle and Baldwin, 1989; Chikunya et al., 1996; Dijkstra et al., 1998). Such variation in type of urinary $\mathrm{N}$ excreted is of relevance in view of environmental issues, because various urinary $\mathrm{N}$ constituents differ widely in their effect of $\mathrm{N}_{2} \mathrm{O}$ release (Dijkstra et al., 2013).

A positive $\mathrm{N}$ balance was established for the low protein diets (on average $28 \mathrm{~g}$ of $\mathrm{N} / \mathrm{d}$, representing $8 \%$ of daily $\mathrm{N}$ intake) and an even larger $\mathrm{N}$-balance for the high protein diets (on average $66 \mathrm{~g}$ of $\mathrm{N} / \mathrm{d}$, representing $14 \%$ of daily $\mathrm{N}$ intake). This positive $\mathrm{N}$-balance could not be ascribed to increased $\mathrm{N}$ retention by the animals as the average BW for the low and high protein treatments at the end of the trial was $19.8 \pm 16.30$ and 10.6 $\pm 12.17 \mathrm{~kg}$ lower, respectively, than at the start of the trial. The positive N-balance in the present study is in line with the average N-balance (39 $\mathrm{g}$ of $\mathrm{N} / \mathrm{d}$ ) reported by Spanghero and Kowalski (1997) in a review on dairy cattle N-balance trials. Spanghero and Kowalski (1997) concluded that volatile $\mathrm{N}$ losses from feces and urine, errors in milk $\mathrm{N}$ analysis, and dermal $\mathrm{N}$ and scurf $\mathrm{N}$ losses together cannot account for the average positive $\mathrm{N}$ balance observed in their study. Other possible sources of $\mathrm{N}$ losses that contribute to a positive N-balance are gaseous $\mathrm{N}$ (Costa et al., 1968) and excretion of $\mathrm{N}$ in urine as nitrate, which is not detected by the Kjeldahl method (Young et al., 1981). In line with the results in our study, Spanghero and Kowalski (1997) observed a positive relationship between $\mathrm{N}$-balance and dietary $\mathrm{N}$ availability. However, we have no conclusive evidence on the background of the increase in positive N-balance observed with the high protein treatment in the present study.

\section{Renal Functioning}

The magnitude of the positive effect of $\mathrm{NaCl}$ intake on urine production was around $0.082 \mathrm{~kg}$ of urine per $\mathrm{g}$ of $\mathrm{Na}$ intake in this study, which is somewhat smaller than the slope of 0.115 established in a meta-analysis of Bannink et al. (1999) and 0.136 observed in an earlier trial (Spek et al., 2012) for lactating cows, but larger 
than the slope of 0.037 found in steers weighing $325 \mathrm{~kg}$ (Thornton, 1970). The size of the effect of $\mathrm{NaCl}$ intake on urine volume may also be affected by other factors related to cow, diet, and environment. The negative relationship between dietary $\mathrm{NaCl}$ and PUN $(P<0.001)$ and between dietary $\mathrm{NaCl}$ and plasma creatinine concentration $(P=0.080)$ can be explained by an increase in the GFR, as the total daily excretion of urea and creatinine in urine was not affected by dietary $\mathrm{NaCl}$. However, although CCR was numerically $7 \%$ higher for the high $\mathrm{NaCl}$ diets compared with the low $\mathrm{NaCl}$ diets, no significant effects of dietary $\mathrm{NaCl}$ on $\mathrm{CCR}(P=$ 0.410) were established. Previously, Spek et al. (2012) also did not observe an effect of $\mathrm{NaCl}$ intake on CCR. In the study by Spek et al. (2012), a positive linear plateau relationship was observed between RRR and CCR. That relationship implies that with an increase of urea transport to the kidneys more urea is recycled to blood. This makes sense as a mechanism for the cow to maintain a certain urea plasma concentration required for urea recycling to the gastrointestinal tract. However, in the present study, a positive relationship between RRR and CCR was found only for the low protein observations $(P=0.023)$, whereas no significant relationship between RRR and CCR for the high protein observations was observed $(P=0.482)$. The UUN was positively related to $\operatorname{CCR}\left(P=0.002, \mathrm{R}^{2}=\right.$ $0.66)$ and tended to be negatively related to RRR ( $P$ $=0.058, \mathrm{R}^{2}=0.34$ ) for the high protein diets, whereas no significant effect of CCR $\left(P=0.983, \mathrm{R}^{2}=0.00\right)$ and $\operatorname{RRR}\left(P=0.156, \mathrm{R}^{2}=0.21\right)$ on UUN was found for the low protein diets, probably because of the low variation in UUN for the low protein diets. This means that an increase in excretion of urea is carried out by (1) an increase of the GFR, and (2) by a reduction of urea recycling from the glomerular filtrate. These 2 UUN regulation mechanisms were also found in other studies (Schmidt-Nielsen and Osaki, 1958; Schmidt-Nielsen et al., 1958; Eriksson and Valtonen, 1982).

\section{Urea Transfer to the Gastrointestinal Tract}

The fact that $\mathrm{K}_{\text {urea }}$ was negatively related to dietary protein content was unexpected because it was hypothesized that an increase in UER, due to an increase in dietary protein intake and a subsequent increase in absorption of rumen $\mathrm{NH}_{3}$ in the blood followed by an increase in urea synthesis by the liver, would increase the dilution rate of PUP. Probably, the $68 \%$ larger PUP for the high protein diets (47.3 g of urea-N) compared with the low protein diets (28.1 g of urea-N) was responsible for this lower $\mathrm{K}_{\text {urea }}$. The negative effect of dietary $\mathrm{NaCl}$ on UER $(P=0.020)$ cannot be explained by a reduced $\mathrm{NH}_{3}$ flux to blood plasma as a result of the negative effect of $\mathrm{NaCl}$ on rumen $\mathrm{NH}_{3}$ concentration (due to an increase in water intake resulting in an increase of rumen fluid passage rate and a reduction in fermentation of dietary protein and a dilution of rumen $\mathrm{NH}_{3}$ ) as we observed no significant effect of dietary $\mathrm{NaCl}$ on rumen concentration of $\mathrm{NH}_{3}$. The fraction of UER returned to the gastrointestinal tract (GER:UER ratio) was negatively related to dietary protein content (Table 5). This negative relationship between dietary protein content and GER:UER ratio was also described by Reynolds and Kristensen (2008), although the observed ratios for the low and high protein diets in this study were higher compared with those predicted by Reynolds and Kristensen (2008) as shown in Figure 4. This difference was likely caused by an underestimated UUN in the present study. According to prediction equations presented by Kebreab et al. (2010), an average UN of 155 and $204 \mathrm{~g}$ of $\mathrm{N} / \mathrm{d}$ would be expected for the low and high protein diets, respectively. These estimates from Kebreab et al. (2010) are 82 and $75 \mathrm{~g}$ of N/d higher than observed in this study for the low and high protein diets, respectively. Moreover, the high positive N-balance observed in this study cannot be explained by $\mathrm{N}$-retention because the cows did not gain weight during the study. It remains unclear in what forms and via which routes this unaccounted $\mathrm{N}$ was lost because leakage of urine from the catheters was negligible and urine was acidified to a $\mathrm{pH}<3.0$, supposed to be sufficient to prevent emission of $\mathrm{NH}_{3}$. However, when assuming that this unaccounted $\mathrm{N}$ originated from urinary urea and attributing the positive N-balance largely to UUN, the estimated GER:UER ratio for the

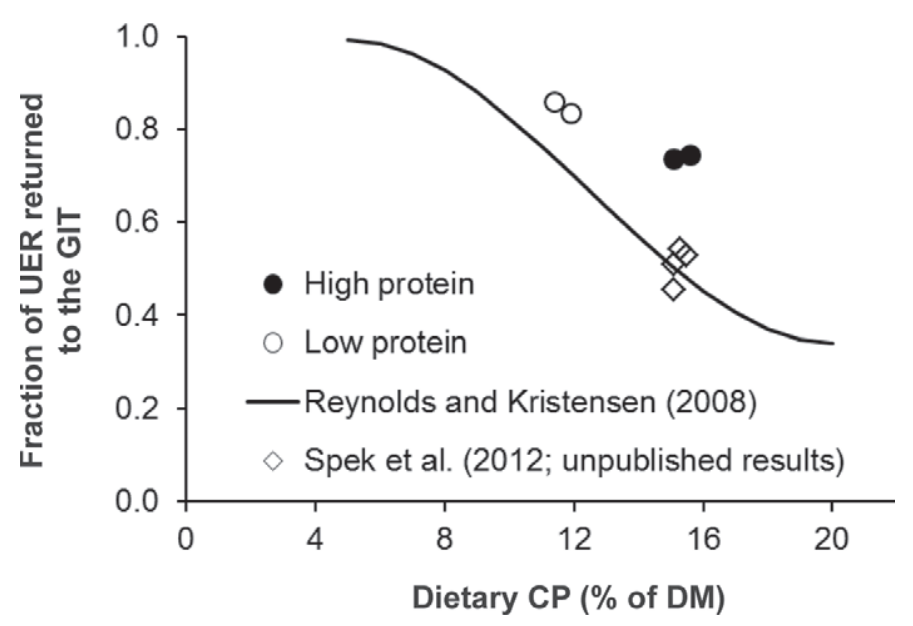

Figure 4. Relationship between dietary $\mathrm{CP}$ and the fraction of plasma urea entry rate (UER) that is returned to the gastrointestinal tract (GIT) in this study for high and low protein diets and in a previous study (Spek et al., 2012). Solid line represents the relationship derived by Reynolds and Kristensen (2008) based on 5 experiments with cattle using dual-labeled $\left.{ }^{15} \mathrm{~N}\right]$ urea infusion studies. 
high protein diet would come close to predicted results reported by Reynolds and Kristensen (2008).

An effect of dietary $\mathrm{NaCl}$ content on the GER:UER ratio was expected, because of the negative effect of dietary $\mathrm{NaCl}$ on PUN and a lower urea concentration gradient between plasma and the rumen (wall); however, no such effect was observed in the present study (Table 5, Figure 4) or in an earlier study by Spek et al. (2012; unpublished results).

\section{CONCLUSIONS}

In this study, MUN, PUN, and UUN were positively related to dietary protein content, whereas the GER:UER ratio was negatively related to dietary protein content. Both MUN and PUN were negatively related to dietary $\mathrm{NaCl}$ content but UUN and GER:UER were not affected. No interaction was found between dietary protein and $\mathrm{NaCl}$ on MUN, UUN, renal parameters, UER, GER, and GER:UER ratio. The relationship between MUN and UUN was significantly affected by dietary $\mathrm{NaCl}$. We conclude that for a proper interpretation of the relationship between MUN and UUN the effect of dietary salt should be considered.

\section{ACKNOWLEDGMENTS}

This study was funded by the Dutch Dairy Board (PZ, Zoetermeer, the Netherlands), the Dutch Product Board Animal Feed (PDV, Zoetermeer, the Netherlands), and the Dutch Ministry of Economic affairs, The Hague, the Netherlands).

\section{REFERENCES}

Abrahamse, P. A., J. Dijkstra, B. Vlaeminck, and S. Tamminga. 2008. Frequent allocation of rotationally grazed dairy cows changes grazing behavior and improves productivity. J. Dairy Sci. 91:20332045

Aguilar, M., M. D. Hanigan, H. A. Tucker, B. L. Jones, S. K. Garbade, M. L. McGilliard, C. C. Stallings, K. F. Knowlton, and R. E. James. 2012. Cow and herd variation in milk urea nitrogen concentrations in lactating dairy cattle. J. Dairy Sci. 95:7261-7268. http://dx.doi.org/10.3168/jds.2012-5582.

Argyle, J. L., and R. L. Baldwin. 1989. Effects of amino acids and peptides on rumen microbial growth yields. J. Dairy Sci. 72:20172027.

Bannink, A., H. Valk, and A. M. Van Vuuren. 1999. Intake and excretion of sodium, potassium, and nitrogen and the effects on urine production by lactating dairy cows. J. Dairy Sci. 82:1008-1018.

Brito, A. F., and G. A. Broderick. 2007. Effects of different protein supplements on milk production and nutrient utilization in lactating dairy cows. J. Dairy Sci. 90:1816-1827.

Broderick, G. A., and S. M. Reynal. 2009. Effect of source of rumendegraded protein on production and ruminal metabolism in lactating dairy cows. J. Dairy Sci. 92:2822-2834.

Burgos, S. A., J. G. Fadel, and E. J. DePeters. 2007. Prediction of ammonia emission from dairy cattle manure based on milk urea nitrogen: Relation of milk urea nitrogen to urine urea nitrogen excretion. J. Dairy Sci. 90:5499-5508.
Chikunya, S., C. J. Newbold, L. Rode, X. B. Chen, and R. J. Wallace. 1996. Influence of dietary rumen-degradable protein on bacterial growth in the rumen of sheep receiving different energy sources. Anim. Feed Sci. Technol. 63:333-340.

Colmenero, J. J. O., and G. A. Broderick. 2006. Effect of dietary crude protein concentration on milk production and nitrogen utilization in lactating dairy cows. J. Dairy Sci. 89:1704-1712.

Costa, G., L. Ullrich, F. Kantor, and J. F. Holland. 1968. Production of elemental nitrogen by certain mammals including man. Nature 218:546-551.

Dai, X.. X. Fang, F. Su, M. Yang, H. Li, J. Zhou, and R. Xu. 2010. Accurate analysis of urea in milk and milk powder by isotope dilution gas chromatography-mass spectrometry. J. Chromatogr. B Analyt. Technol. Biomed. Life Sci. 878:1634-1638.

De Campeneere, S., D. L. De Brabander, and J. M. Vanacker. 2006. Milk urea concentration as affected by the roughage type offered to dairy cattle. Livest. Sci. 103:30-39.

Dijkstra, J., J. France, and D. R. Davies. 1998. Different mathematical approaches to estimating microbial protein supply in ruminants. J. Dairy Sci. 81:3370-3384.

Dijkstra, J., O. Oenema, J. W. van Groenigen, J. W. Spek, A. M. van Vuuren, and A. Bannink. 2013. Diet effects on urine composition of cattle and $\mathrm{N}_{2} \mathrm{O}$ emissions. Animal 7:292-302.

Draaijers, G. P. J., W. P. M. F. Ivens, M. M. Bos, and W. Bleuten. 1989. The contribution of ammonia emissions from agriculture to the deposition of acidifying and eutrophying compounds onto forests. Environ. Pollut. 60:55-66.

Eriksson, L., and M. Valtonen. 1982. Renal urea handling in goats fed high and low protein diets. J. Dairy Sci. 65:385-389.

European Union. 2009. 152/2009/EC: Laying down the methods of sampling and analysis for the official control of feed. Official J. L 166:9-15.

Godwin, I. R., and V. J. Williams. 1984. Renal control of plasma urea level in sheep: The diuretic effect of urea, potassium and sodium chloride. Q. J. Exp. Physiol. 69:49-59.

Gonda, H. L., J. E. Lindberg, and J. Bertilsson. 1995. Effect of level and degradability of rapeseed meal in rations for dairy cows: 2 . Diet digestibility, dietary nitrogen partition and urinary purine derivatives excretion. Acta Agric. Scand. A Anim. Sci. 45:36-44.

Howarth, R. W., G. Billen, D. Swaney, A. Townsend, N. Jaworski, K. Lajtha, J. A. Downing, R. Elmgren, N. Caraco, T. Jordan, F. Berendse, J. Freney, V. Kudeyarov, P. Murdoch, and Z. ZhaoLiang. 1996. Regional nitrogen budgets and riverine N \& P fluxes for the drainages to the North Atlantic ocean: Natural and human influences. Biogeochemistry 35:75-139.

Hristov, A. N., M. Hanigan, A. Cole, R. Todd, T. A. McAllister, P. M. Ndegwa, and A. Rotz. 2011. Ammonia emissions from dairy farms and beef feedlots: A review. Can. J. Anim. Sci. 91:1-35.

Huhtanen, P., J. I. Nousiainen, M. Rinne, K. Kytölä, and H. Khalili. 2008. Utilization and partition of dietary nitrogen in dairy cows fed grass silage-based diets. J. Dairy Sci. 91:3589-3599.

Hutchings, N. J., S. G. Sommer, J. M. Andersen, and W. A. H. Asman. 2001. A detailed ammonia emission inventory for Denmark. Atmos. Environ. 35:1959-1968.

IPCC (Intergovernmental Panel on Climate Change). 2006. Guidelines for National Greenhouse Gas Inventories. Volume 4: Agriculture, Forestry and Other Land Use. Prepared by the National Greenhouse Gas Inventories Program. H. S. Eggleston, L. Buendia, K. Miwa, T. Ngara, and K. Tanabe, ed. Institute for Global Environmental Strategies (IGES), Kanagawa, Japan.

ISO (International Organization for Standardization). 1997. Animal Feeding Stuffs. Determination of nitrogen content and calculation of crude protein content-Kjeldahl method. ISO 5983:1997. ISO, Geneva, Switzerland.

ISO (International Organization for Standardization). 1999. Animal Feeding Stuffs. Determination of moisture and other volatile matter content. ISO 6496:1999. ISO, Geneva, Switzerland.

ISO (International Organization for Standardization). 2000a. Animal Feeding Stuffs. Determination of starch content-Polarimetric method. ISO 6493:2000. ISO, Geneva, Switzerland. 
ISO (International Organization for Standardization). 2000b. Animal Feeding Stuffs. Determination of the contents of calcium, copper, iron, magnesium, manganese, potassium, sodium and zinc Method using atomic absorption spectrometry. ISO. 6869:2000. ISO, Geneva, Switzerland.

ISO (International Organization for Standardization). 2004. Milk. Determination of urea content-Enzymatic method using difference in $\mathrm{pH}$ (Reference method). ISO 14637:2004. ISO, Geneva, Switzerland.

ISO (International Organization for Standardization). 2006. Animal Feeding Stuffs. Determination of amylase-treated neutral detergent fibre content (aNDF). ISO 16472:2006. ISO, Geneva, Switzerland.

ISO (International Organization for Standardization). 2008. Animal Feeding Stuffs. Determination of acid detergent fibre (ADF) and acid detergent lignin (ADL) contents. ISO 13906:2008. ISO, Geneva, Switzerland.

Kauffman, A. J., and N. R. St-Pierre. 2001. The relationship of milk urea nitrogen to urine nitrogen excretion in Holstein and Jersey cows. J. Dairy Sci. 84:2284-2294.

Kebreab, E., A. B. Strathe, J. Dijkstra, J. A. N. Mills, C. K. Reynolds, L. A. Crompton, T. Yan, and J. France. 2010. Energy and protein interactions and their effect on nitrogen excretion in dairy cows. Pages 417-425 in Proc. 3rd EAAP In. Symp. Energy and Protein Metabolism and Nutrition. G. M. Crovetto, ed. Wageningen Academic Publishers, Wageningen, the Netherlands.

Korhonen, M., A. Vanhatalo, and P. Huhtanen. 2002. Effect of protein source on amino acid supply, milk production, and metabolism of plasma nutrients in dairy cows fed grass silage. J. Dairy Sci. 85:3336-3351.

NRC. 2001. Nutrient Requirements of Dairy Cattle. 7th rev. ed. Natl. Acad. Press, Washington, DC

Pain, B. F., T. J. Van der Weerden, B. J. Chambers, V. R. Phillips, and S. C. Jarvis. 1998. A new inventory for ammonia emissions from U.K. agriculture. Atmos. Environ. 32:309-313.

Polan, C. E., C. N. Miller, and M. L. McGilliard. 1976. Variable dietary protein and urea for intake and production in Holstein cows. J. Dairy Sci. 59:1910-1914.

Powell, J. M., M. A. Wattiaux, and G. A. Broderick. 2011. Short communication: Evaluation of milk urea nitrogen as a management tool to reduce ammonia emissions from dairy farms. J. Dairy Sci. 94:4690-4694.

Rabinowitz, L., R. A. Gunther, and E. S. Shoji. 1973. Effects of high and low protein diets on sheep renal function and metabolism. Kidney Int. 4:188-207.

Reynolds, C. K., and N. B. Kristensen. 2008. Nitrogen recycling through the gut and the nitrogen economy of ruminants: An asynchronous symbiosis. J. Anim. Sci. 86(14 Suppl.):E293-E305.
Roseler, D. K., J. D. Ferguson, C. J. Sniffen, and J. Herrema. 1993. Dietary protein degradability effects on plasma and milk urea nitrogen and milk nonprotein nitrogen in Holstein cows. J. Dairy Sci. 76:525-534.

Ruiz, R., L. O. Tedeschi, J. C. Marini, D. G. Fox, A. N. Pell, G. Jarvis, and J. B. Russell. 2002. The effect of a ruminal nitrogen (N) deficiency in dairy cows: Evaluation of the Cornell Net Carbohydrate and Protein System ruminal N deficiency adjustment. J. Dairy Sci. 85:2986-2999.

Satter, L. D., and L. L. Slyter. 1974. Effect of ammonia concentration on rumen microbial protein production in vitro. Br. J. Nutr. $32: 199-208$.

Schmidt-Nielsen, B., and H. Osaki. 1958. Renal response to changes in nitrogen metabolism in sheep. Am. J. Physiol. 193:657-661.

Schmidt-Nielsen, B., H. Osaki, H. V. J. Murdaugh, and R. O'Dell 1958. Renal regulation of urea excretion in sheep. Am. J. Physiol. 194:221-228.

Searle, P. L. 1984. The Berthelot or indophenol reaction and its use in the analytical chemistry of nitrogen. A review. Analyst (Lond.) 109:549-568.

Spanghero, M., and Z. M. Kowalski. 1997. Critical analysis of N balance experiments with lactating cows. Livest. Prod. Sci. 52:113122

Spek, J. W., A. Bannink, G. Gort, W. H. Hendriks, and J. Dijkstra. 2012. Effect of sodium chloride intake on urine volume, urinary urea excretion, and milk urea concentration in lactating dairy cattle. J. Dairy Sci. 95:7288-7298.

Spek, J. W., J. Dijkstra, G. Van Duinkerken, and A. Bannink. 2013. A review of factors influencing milk urea concentration and its relationship with urinary urea excretion in lactating dairy cattle. J. Agric. Sci. 151:407-423.

Thornton, R. 1970. Factors affecting the urinary excretion of urea nitrogen in cattle. I. Sodium chloride and water loads. Aust. J. Agric. Res. 21:131-144.

Van Duinkerken, G., M. C. Blok, A. Bannink, J. W. Cone, J. Dijkstra, A. M. Van Vuuren, and S. Tamminga. 2011. Update of the Dutch protein evaluation system for ruminants: The DVE/OEB2010 system. J. Agric. Sci. 149:351-367.

Van Es, A. J. H. 1975. Feed evaluation for dairy cows. Livest. Prod. Sci. 2:95-107.

Weeth, H. J., and L. H. Haverland. 1961. Tolerance of growing cattle for drinking water containing sodium chloride. J. Anim. Sci. $20: 518-521$

Young, V. R., N. S. Scrimshaw, and D. M. Bier. 1981. Whole body protein and amino acid metabolism: Relation to protein quality evaluation in human nutrition. J. Agric. Food Chem. 29:440-447. 